УДК $\quad 930.2: 77$

DOI https://doi.org/10.31212/tokovi.2020.3.mit.247-268

Критичко издање научне грађе

Примљено: 12. 5. 2020.

Прихваћено: 1. 10. 2020.

Filip MITRIČEVIĆ

Indiana University Bloomington, Indiana, USA

fmitric@iu.edu

\title{
The Ways in Which I Never Thought About My Great-Grandfather: An Essay on the Potentials of Photography as a Historical Document ${ }^{*}$
}

\begin{abstract}
This paper is on the trail of answering the theoretical question of the potential of photography as a historical source. The paper does not aim for a historical reconstruction in the classical sense but is an attempt to show the reach of this visual media in historical research, based on the correlation of a sample of family photographs, oral history, and theory. By employing the author's "personal voice," the paper attempts to correlate particularities with a broader context and general theory. The author uses photographs of his great-grandfather, made at a prisoner-of-war camp during the World War II, to show the limitations of photography as a historical source.

KEY WORDS: Photography, World War II, Historiography, Sources, Roland Barthes
\end{abstract}

Our lives are such that we are constantly immersed in an endless sea of images. Modern technology has made photography ever reachable and present, abundant in quantity, continually improving in technical quality, yet utterly mundane. Rarely do we stop to think about this medium, its history, its significance, and above all, its potential. Again, why

This paper is a product of cooperation with Professor Daniel "Danny" James on a course titled Photography and the Historical Archive, held at Indiana University Bloomington during the spring semester of academic year 2019-2020. I owe many thanks to Prof. James for his inspiration and guidance through this endeavor and to my colleague Richard Levi Raber for his comments on my earlier drafts. 
would most of us ever think about something that ceased to be a novelty a long time ago? ${ }^{1}$ Even we, historians, rarely think of the infinite promiscuity of the photo and its elusive nature; to us, it is more often an illustration, or sometimes a mute piece of evidence - a two-dimensional record that we accept as-is and take for granted. ${ }^{2}$ Julia Adeney Thomas is right in saying that photographs flirt with us. ${ }^{3}$ They flirt with our imagination, our understanding of the world, space, and time, our emotions. And as often happens, some nuances of that flirtatiousness evade our senses for a long time. Rarely do we ask specific questions about photography, and even rarer do we think about it in particular ways. Then, we may end up taking a graduate seminar that deals with the nature of photography as a medium and its relationship to history - and it makes us reconsider.

In my possession I hold a series of photographs of a man with a receding hairline, in a military uniform, often surrounded by other soldiers, and often in front of some brick buildings. I was told early in life that he was my great-grandfather. I never met him, or rather, I do not remember him because he died a year after my birth. However, my connection to this man is not only familial but somewhat emotional. My mom always perpetuated the bond by telling me that I resembled him physically more than anyone else, him being 6 foot four and wearing size 12 boots (I am 2" behind, and a full size down). A member of the Royal Guard in the Army of the Kingdom of Yugoslavia, taken prisoner in 1941 by the Wehrmacht, he was transported to a labor camp near Cologne from where he returned home in 1945. If he had not, I would not have heard this story from my grandfather, who was born in 1946. The photographs he sent to my great-grandmother during the war would never provide for the "duality" of my relationship to this past, as defined by Thomas - "a relationship that is both visceral and discursive, both instinctual and interpretive,

1 In that context, it is highly illustrative how Walter Benjamin saw the development of photography until 1931. Cf. Walter Benjamin, A Short History of Photography, (Oxford: Oxford University Press, 2011).

2 An exception is a book by Georges Didi-Huberman, a voluminous study of the four only known photographs made in Auschwitz during the Second World War. Cf. Georges Didi-Huberman, Images in Spite of All. Four Photographs from Auschwitz, (Chicago: Chicago University Press, 2008).

3 Julia Adeney Thomas, "The Evidence of Sight," History and Theory, Theme Issue 48 (December 2009), 151-168. 
both voluptuous and analytical." ${ }^{4}$ There would be no me to ask the questions. We can say that the emotion there is implied.

Having said all that, a question emerges: What are the limits of my "recognition" of the photographs of my great-grandfather? The inherent "likeness" which I am supposed to observe and acknowledge - especially according to my mother - is left unsatisfied as I never met the man, nor was he a part of my lived experience. Although I cannot escape the obvious connection and even though my present is supposed to intersect with this piece of the past, to me, it is a "shard." For my mother and grandfather, these pictures represent an object of "recognition" and "likeness," relying on "the non-discursive perception of similarity and differences." Still, for me, they constitute a site of "excavation" for artifacts with which I am to establish "the network of connotations, practices, and relations of power - in short, the entire discursive system - through which it emerged as an object." 5

In a Barthesian sense, for me my great-grandfather falls under History (with a capital H), as the great French thinker asked: "Is History not simply that time when we were not born?"' Mourning the death of his mother, Roland Barthes was trying to reconstruct his memory of her based on an old photograph. Coming to grips with a representation of his mother that falls outside of his memory, Barthes defined the distance as such:

"Thus the life of someone whose existence has somewhat
preceded our own encloses in its particularity the very
tension of History, its divisions. History is hysterical: it is
constituted only if we consider it, only if we look at it -
and in order to look at it, we must be excluded from it. As
a living soul, I am the very contrary of History, I am what
belies it, destroys it for the sake of my own history (im-
possible for me to believe in 'witnesses'; impossible, at
least, to be one; Michelet was able to write virtually noth-

4 Thomas, "The Evidence of Sight", 151.

5 The term "recognition" is defined within the associations of an observer which a particular image evokes, based on lived experiences. Opposite to "recognition" is "excavation," a term that outlines the process in which observer is facing associations which go beyond his lived experience and are susceptible to critical analysis. The "likeness" presents every resemblance which aligns with the observer's memory, while a "shard" is defined within the scope of artefacts and associations which fall outside of one's own experience. Thomas, "The Evidence of Sight", 153, passim.

6 Roland Barthes, Camera Lucida. Reflections on Photography, (New York: Hill and Wang, 2010), 64. 
ing about his own time). That is what the time when my mother was alive before me is - History (moreover, it is the period which interests me most, historically)."

Though these photographs - and my existence for that matter are proof that this man, Živan Vuković, really existed, the "reader" of these images (again, me) has fallen into the abyss of discontinuity which John Berger discusses in Another Way of Telling. ${ }^{8}$ These photographs represent a moment captured in the past, distant and disconnected from my present, whose ambiguity is now an object of analysis. As Liz Wells suggests, based on Mary Price's theory, "There is no single meaning for a photograph, but rather an emergent meaning, within which the subject-matter of the image is but one element." "The focus," she further stipulates, "is upon the clues which together constitute a text ready for reading and interpretation." ${ }^{10}$

The text which Liz Wells is referring to is both literal and metaphoric. Correct in that photographs have no language of their own as they are "produced instantaneously by the reflection of light," John Berger is also right in that photos beg for interpretation. Another way of saying that photographs sometimes come with words, but they always necessitate some sort of text for a closer examination - "The photograph, irrefutable as evidence but weak in meaning, is given a meaning by the words." ${ }^{11}$ In that sense, my search is blessed with the letters and fragments of the oral history that came with the photos, providing some context and lessening the ambiguities. ${ }^{12}$ However, many questions remain, mostly questions that I would ask as Filip the historian, not the great-grandson: Who is this prisoner of war? What is the greater history of all of those like him?

$7 \quad$ Barthes, Camera Lucida, 65.

8 Cf. John Berger, Jean Mohr, Another Way of Telling, (New York: Pantheon, 1982).

9 Liz Wells, Photography: A Critical Introduction, (London: Psychology Press, 2004), 28.

10 Wells, Photography, 29.

11 Berger, Another Way, 92.

12 Discussing the relationship of the social documentary with "the symbolic environment", John Louis Lucaites came to one general conclusion applicable here: "The relationship between 'word' and 'image' has always been central to the rhetorical power of any historical remembrance, but in the 1930s that relationship took on a special significance as still photography emerged as a primary medium of public and political discourse, giving visual and apparently concrete presence to those images that in verbal discourse were 'nameless' and 'unreasoning'." John Louis Lucaites, "Visualizing 'The People': Individualism vs. Collectivism in Let Us Now Praise Famous Men," The Quarterly Journal of Speech 83/3 (August 1997), 271. 
And yet, what is his microhistory? Why do these photographs even exist, why were they made? What can we learn from them?

The things I definitely know about Živan Vuković, my maternal great-grandfather, can be summarized easily in a few sentences. He was born in 1911 in a small village called Szatrinca/Šatrinci, in what was then the southern borderland of Austria-Hungary. A member of the Royal Guard of the Kingdom of Yugoslavia at the outbreak of World War II, he was taken prisoner in April of 1941 and deported to Germany, where he spent time interned in a POW camp, Stalag 6G, and working for a local family. After the war, he came back to his wife and three children, to what was then the Democratic Federative Yugoslavia. According to family stories, he had not encountered any problems with the new socialist authorities. He went back to farming on what was now the state proclaimed "maximum" of land (how it was widely referred to) and continued a relatively peaceful life until he died in 1991. In 1946 he had his youngest son, his fourth and last child, my grandfather Borko. In the house that he eventually left to this youngest son, in the bottom drawer of a wooden cabinet, there was a set of photos of my great-grandfather that had been lying there for decades on top of a pile of family photos that were never in an album, along with some letters, a metal spoon of gigantic proportions, and a porcelain bowl with a swastika on the bottom side. The spoon he used in the camp. The bowl was a "souvenir," now "kept safe" by my grandfather out of fear that the universally recognized symbol could be misconstrued somehow by others or be sold "to some evil people on the internet who like these things. In case of hard times, if we need some money." The photos and the letters had been sent from the camp to my great-grandmother. However, one letter with two photos was sent to Živan in 1953 by a woman from Germany, but we will come to that later.

Thinking about these photos and their place in history, as well as this one man's place in history, we cannot but wonder about the relationship between Živan, the soldier, and a global war that was (and was not) happening around him. Why was it not? Well, the photos are not of the war or even of its active participants. However, these photographs depict one particular kind of war experience and are also very reflective of some of its characteristics. Trying to decipher the potential of a photograph as a historical document, Kevin Coleman argues in his book A Camera in the Garden of Eden that the separation of the subject represented in the photo and the structures, ideologies, or discourses revolving around 
that subject, is not possible. ${ }^{13}$ To Coleman, the subject is inseparably tied to the "historical and place-specific formations," to which he assigns capitalist production, gender, nationalism, or religion, among others. "Rather," Coleman posits, "I maintain that the photo always indexes a subject in her place or in the place that she pretends to be. Hence if a photo happens to index a subject in itself, it is always also marking the split between the subject-in-becoming and the society, norms, ideals, and material culture in which that subject finds herself." ${ }^{\prime 4}$ In other words, the photo captures not only a person but also the place and the circumstances in which that person is found. The main difficulty is how to interpret these circumstances. Drawing from Ariella Azoulay's work, Coleman provided a diagram that represents the distinction of the two moments labeled as "the event of photography" and "the photographic event." The photographic event represents the sliver of time when a given photo was taken, as opposed to a broader slice of the time axis, the event of photography, which encompasses all of "the circumstances that led to the creation of a given photograph and all of the possible encounters with that image after it was made." Following the potential developments of the jotted line of the future on the time axis, Coleman asserts that the event of photography stays "always unfinished and open to reengagement." ${ }^{15}$ For the subject of my photos, the event of photography is not only the global conflict engulfing the whole of humanity for six gruesome years but also the time from it to now. The photographic event is the unknown time spent in a German prisoner-of-war camp. The jotted line of the future represents all the ensuing interactions and interpretations of the photos.

Figure 1 presents a man wearing a military uniform standing in front of a brick building with two wooden doors. For someone with extensive knowledge of interwar and World War II military history, interested in Yugoslav history as well, the uniform could look like one belonging to a member of the Kingdom of Yugoslavia army corps. The man assumed a semi-relaxed position, his balance on the right leg, while his left foot is sticking out of the center of balance - showing us the profile of his dark, army-style boot. He is not wearing a cap, so his very short and dark hair

13 Cf. Kevin Coleman, A Camera in the Garden of Eden: The Self-Forging of a Banana Republic, (Austin: University of Texas Press, 2016).

14 Coleman, A Camera in the Garden of Eden, 27.

15 Ibid. Cf. Ariella Azoulay, The Civil Contract of Photography, (New York: Zone Books, 2008); Ariella Azoulay, Civil Imagination: A Political Ontology of Photography, (London - New York: Verso, 2011). 
reveals a receding hairline. From the shadow of his nose, a mustache appears just slightly. While his right arm is dangling freely next to his body, the left one is twisted in the elbow and occupied with a cigarette. The building behind him does not reveal much, except that it is emanating an ominous feel; made of bricks from the bottom to the top, the only features visible are the two wooden doors with strong metal hinges and locks, one of them a two-section door. Not a lot of context, until we go to the accompanying letter, that is.

Writing in April of 1942 to his wife, Vukica, Živan Vuković states from the get-go that he is of good health and that he hopes and wishes the same for his family. While saying that he misses them a lot, he expresses hesitance about writing and sending pictures of himself before he receives a letter from home. However, because one never came, he eventually decided to write and to send the photographs, which he hopes are a good representation of his likeness, "for a long-lasting memory of me." He admits that he is not happy with how the photos turned out, but still believes the family will be able to recognize him, as he "hasn't changed much." He writes extensively about his concerns about the logistics of mailing the letters, and how long they will travel. He wishes a happy Easter to his loved ones, enquires about the family, in-laws, and neighbors, and describes a dream he had about himself being home. Yet, none of it is interesting beyond the moment in which he expresses his concern with the likeness of the image. Though we know nothing about the circumstances in which the image was taken, it matters less at this point. Whether or not this picture was made by a German guard or by somebody from the ranks of the prisoners, it represents a classic example of a "portrait." The subject's main concern is that the picture is an adequate representation of his likeness for his family to see him as they remember him, and to keep remembering him (in case he never comes back).

Figure 1 is also extraordinary in that, unlike the other photographs, it is not a collective portrait, and it is the only one where the "performative" aspect is at least slightly lessened; the photo almost resembling a spontaneous "snapshot." However, we have seen from the letter that there existed an element of self-obsession with appearance. Though the obsession comes with a function, it is still meant to represent a portrait in a classical sense. Yet, we must ask what a "portrait" actually is and what is the performative aspect of a photograph? Writing about the performative aspect of portraits due to the subjects' awareness of the photographer (granted while discussing documentarist photography), Walter Benn Mi- 
chaels claims, "Because the photograph requires a subject who can perform and because the presence of the photographer can be understood in itself to elicit a kind of performance, the task of the photographer must be to overcome or neutralize that performance." ${ }^{16}$ I am employing this claim to state precisely the opposite when it comes to the next set of pictures up for analysis. Though photography, by nature, serves as a documentarist media, these particular photographs are lacking a tangible documentarist capacity and represent nothing more than a portrait.

Figures 2-4 are collective portraits. What is especially interesting is that the soldiers in them are often smiling, presenting a relaxed and happy appearance. Similarly, they are often holding some musical instruments (guitar, accordion, banjo, or flute). It would seem that the instruments in the pictures are the same (at least the guitar, banjo, and accordion), but always held by a different person. In fact, my great-grandfather is holding an accordion and a guitar in two of them. Maybe it is unsurprising that somebody would know how to play those two, but from the testimonies of my grandfather, Živan never played a musical instrument in his life. Everything about these three photos can be associated with what Roland Barthes has come to define as the photographs' studium. "What I feel about these photographs derives from an average affect, almost from a certain training," Barthes wrote, "I did not know a French word which might account for this kind of human interest, but I believe this word exists in Latin: it is studium, which doesn't mean, at least not immediately, 'study, but application to a thing, taste for someone, a kind of general, enthusiastic commitment, of course, but without special acuity." ${ }^{17}$ Thus, we come to the definition of my interest in these photos: a committed exploration of the limits of knowledge coming from a medium, performed by a trained individual - "A kind of education," Barthes would say. But what slashes through the reading of photos in terms of the studium is their punctum.

"The second element will break (or punctuate) the studi$u m$. This time it is not I who seek it out (as I invest the field of the studium with my sovereign consciousness), it is the element which rises from the scene, shoots out of it like an arrow, and pierces me. A Latin word exists to des-

16 Walter Benn Michaels, The Beauty of a Social Problem: Photography, Autonomy, Economy, (Chicago: University of Chicago Press, 2015), 118. 
ignate this wound, this prick, this mark made by a pointed instrument: the word suits me all the better in that it also refers to the notion of punctuation, and because the photographs I am speaking of are in the effect punctuated, sometimes even speckled with these sensitive points; precisely, these marks, these wounds are so many points. This second element which will disturb the studium I shall therefore call punctum; for punctum is also: sting, speck, cut, little hole - and also a cast of the dice. A photograph's punctum is that accident which pricks me (but also bruises me, is poignant to me)." 18

Should we, then, conclude that the "snafu" with the musical instruments represents the punctum of these photographs? After all, it jumped up and bit my nose, slashing through the logic of the narrative building. Is that the elusive detail that subconsciously grabbed my attention? Yes and no. Yes, in that it is a "sting, a speck, a hole." But no in that it is not accidental. The orchestration present in these photos shows the intention of the Operator falling outside of what might be construed as the punctum. Therefore, the mentioned detail would remain under the umbrella of the studium, "which allows me to discover the Operator, to experience the intentions which establish and animate his practices, but to experience them 'in reverse,' according to my will as a Spectator". ${ }^{19}$

Unfortunately, there is no way for us to know who took these photos - if they were produced by the German authorities or by the prisoners themselves. Therefore, we cannot possibly know what the ultimate purpose of the photos was. Were they taken by the Germans to present the conditions in the camps as livable and acceptable? Or were they staged by the prisoners themselves to present the image of their well-being to their concerned families? Maybe they were taken by the prisoners who, more than anything, were concerned with their likeness and presentation, wanting, perhaps, to cherish the memories of the hardships through rose-tinted glasses. There is no way to determine this. However, what is common to all of these potential scenarios is that the representation is based on a lie. It is either voluntary or forced propaganda, a perpetuation of (self)indulgence to a particular image, and the subject's "obses-

18 Ibid., 26-27.

19 Ibid., 28. 
sion with going down to posterity."20 In that sense, they are as far as possible from the Walter Benn Michaels' definition of a documentarist photo. Though these photos are by their very nature a historical document, a potential source of historical knowledge, they are highly performative, and thus they qualify as portraits.

Whether these photos were a propagandistic tool by the Germans, a gimmick by the prisoners to mitigate the concerns of their families, or a physical artifact of the mental escape from the everyday horrors of the camp (a sort of auto-falsified memory, if you will), we can say with fair certainty that the real camp life is not represented in them. However, besides being able to say that the living conditions were probably not far from being described as deplorable, there is not much direct evidence to say what it resembled. The letters do not say much. Within my family circles, there is somewhat of a family myth - a story stemming from a story - which my great-grandfather confided after the war: that the prisoners sometimes had to resort to eating undigested corn from horse dung to survive. Obviously, there is no way of confirming this, and it remains a second-hand piece of oral family history. A possible confirmation that the described situation was plausible is the testimony of an American POW who was at Stalag 6G some two and a half years later. Just how comparable the situation was, we cannot say. Still, Private Clarence Earl Derrington Junior, born in Meridian, Mississippi, remembered his days at the camp as days when food was scarce. In an interview conducted on January 15, 2015, then 90-year-old Derrington told the interviewer that "The Germans didn't bother us. And they just didn't feed us." ${ }^{21}$ In a separate interview with the local media, Derrington said: "They would feed us a loaf of bread, and we'd have to divide it into seven different pieces. Every time you got the bread, you had to make it last until the next loaf." 22

One vignette from the oral history of Clarence Earl Derrington that is interesting in the context of my great-grandfather's photographs is the story of the funeral of one of his fellow inmates. After the young

20 Michaels, The Beauty, 114.

21 Video of the conversation with Clarence Earl Derrington Junior from January $15^{\text {th }}$, 2015, accessed on April 9th, 2020, http://www.americainworldwartwo.amdigital. co.uk.proxyiub.uits.iu.edu/Documents/Details/OH_3543_AM,

22 Dustin Barnes, "Jackson man recalls POW time in WW2", The Clarion Ledger, June 5, 2014, accessed on April 9th, 2020, https://www.clarionledger.com/story/ news/2014/06/05/jackson-man-recalls-time-nazi-pow-camp-wwii/10048281/ 
soldier died, Derrington and a few other soldiers were selected by the Germans to take the body and bury it in Bonn. Going back to our collection, one of the photographs (Figure 5) is of what is obviously a funeral. In it, roughly one and a half dozen soldiers are standing around a burial mound covered with reefs and ribbons inscribed with the words "Eternal requiem - Your comrades from R.K. 415 - Last goodbye - From your folk from Neradin." The geographical determinant in the far-right piece of the ribbon is the most interesting. Neradin is a neighboring village to my great-grandfather's, today separated by maybe $8 \mathrm{~km}$ of a narrow asphalt road - most probably a dirt road at that time. Who is the deceased, what is his connection to my great-grandfather? Was he a friend or an acquaintance? Did they share a camaraderie based on a similar geographical background, or did their families know each other? There is no way of telling. Again, could it be that all of the soldiers in this picture came from Neradin? It is hard to imagine that 18 or 19 prisoners seen in the photo found themselves in the same POW camp in Germany, coming from a village that now has a population of 500 people. Then again, the ribbon is inscribed in plural, suggesting that there is more than one of them there. Could it have been that the photo was intended for his family in Neradin (represented by the plural on the ribbon), but never made it? We will never know. Returning to the story of Earl Derrington for a second, it is also hard to imagine that the German authorities would let so many prisoners attend a funeral outside of the camp. That is, at least, one testimony of the Germans changing practices, probably brought on by the circumstances of the war, as well as the ceiling of our potential excavation of data from this photograph.

As mentioned before, bundled alongside the photographs and the letter sent from the camp were two photographs and a letter that my great-grandfather received from Germany, years after he returned. In a letter written on December 15, 1953, a woman named Lina proclaims how glad and surprised she is that they (she and her family), finally, after many years, have heard some news about Živan and that receiving the letter brought them a lot of happiness. "We think of you often. We have a few photos of you, and every time we look at them, we cannot but think of you. We are delighted that you are with your family, taking care of them." Here is the moment where we find out that there is a parallel set of photos representing Živan Vuković, a Yugoslav prisoner of war. In this family's possession is a collection of images that represents an object of memory of a person and a time. The emotional connection 
they have (or she has, even though the letter is written in plural) is of fondness and a sense of nostalgia. These images are an artifact of their shared past with the same man in two sets of photographs, as well as an object to gather around. That becomes even more obvious when Lina, in her own words, tries to bridge the gap of 8 and a half years "since you've been with us." Unfortunately, she had to bring the news that her father died in 1951. Mom is doing fine. Crystof came back home as soon as the war ended (meaning that he had never met Živan but was without a doubt the subject of many stories), got married, and bought himself a tractor. He has no children. Betty (the sister?) is married with two kids, ages 4 and 2. "I am traveling every day to Cologne, to work at an office." "We wish to see you once more here."

Two photographs came with the letter. One photo (Figure 6) is of a young woman sitting on a rail fence on the coast of a lake or a sea; she is wearing sandals and a dress with puffy shoulders, and her hair is braided and pulled together at the back. She is wearing a watch on her left wrist. The other photo is of an older woman wearing a black dress, two young children standing in front of her. The kids are blonde with puffy hair, an older girl and a younger boy, not older than 4-5 and 2-3. Is that Lina in the first photo? Could the mother be in the second one, with Betty's children? The questions we can ask about these two photos are almost endless. Why is there a picture of Lina, if we assume that she, as the author of the letter is in it? Is she sending a photo of herself precisely because she is doing the writing? It is not hard to imagine that the responsibility fell to her because, well, there was no one else: the father had died, mother could have been too old, or illiterate; Crystof and Betty had left the family home, and Lina was the only one left, she was not married. Were these the only photos of her family that she had lying at hand?

My grandfather always likes to say that he has no doubts about his father "sowing his wild oats" around Germany and that he, for sure, has brothers and sisters there. It was not uncommon for POWs to establish romantic relationships with local females, even though it implied significant legal repercussions for the women. ${ }^{23}$ Can we observe a hint of romance between my great-grandfather and Lina? Would that be too much conjecture, or is it a plausible scenario? Živan could have been 31 at the

23 Raffael Scheck, "Collaboration of the Heart: The Forbidden Love Affairs of French Prisoners of War and German Women in Nazi Germany", The Journal of Modern History 90 (June 2018), 351-382. 
youngest when he came to their family. If we take the photo that came with the letter in 1953 as a recent representation of Lina, she could not have been more than a teenager during the war. Her father was alive. How plausible would a romantic connection between a young German girl and a Slavic prisoner and forced laborer be? Was she infatuated with him, or did she see in him a brotherly figure - a substitute for Crystof who had gone off to fight? Was she just remembering with fondness this man who had spent a lot of time with the family, and it was, by chance, up to her to respond to his letter? Despite my grandfather's wishes and dreams, there is no way of knowing.

What can we, ultimately, conclude about the potential of photos as historical sources? More than the great-grandfather's place in my life, these photos are shards of the history they pertain to, what Daniel James and Mirta Lobato refer to as a "permanent tension between universal metanarratives and the particular: the fragmentary, momentary, and fleeting experience that they also register."24 Even in their documentarist capacity, they are limited. Usually, photographs invoke more questions than they actually answer. Therefore, it would not be harsh to say that, at best, photographs occupy the liminal space between knowledge and the lack of it. Our example was quite illustrative of that judgment. By saying that, we are not (and we could not be) taking away the incredible capacity of the photo to capture an instance, sometimes crucial for factual confirmation. However, reducing history to a series of photo-finishes is not only speculative and conjectural in nature, but potentially dangerous. One needs only to glance at Facebook or Instagram to see just how much. As much as our time seems like a "Question everything" time, it is more often a "Question nothing" moment in history. John Berger's questions on the deficiencies of the contextual aspect of the photos that come to mind, I feel are best summarized by James and Lobato:

"For an analyst like John Berger, who has puzzled over the issue of photos and narrative more than most, the photograph represents a particular instant that is captured in a decontextualized way. The very act of taking a photo implies discontinuity and rupture - the removal of a momentary fragment from the continuum of time. This decon-

24 Daniel James, Mirta Zaida Lobato, “Family Photos, Oral Narratives, and Identity Formation: The Ukrainians of Berisso", Hispanic American Historical Review 84, (February 2004), 16. 
textualization compromises the narrative capacity of the photo. For Berger, ' $[\mathrm{I}] \mathrm{t}$ is a vision of the world that refuses interconnection, continuity, but which confers on each moment a mysterious character.' From this perspective, the photograph (especially the photo in the public realm) cannot narrate or (unlike memory) conserve within itself any wider signification. Berger argues that photography's fundamental lack of context creates an inevitable ambiguity that no amount of detailed analysis can dispel."25

Even as an invoker of memory, we have also seen the limits of photography. The border is drawn at the last generation with an actual memory of the photograph's subject. This border is where the "recognition" ends, and the "excavation" begins. The photographs that we have seen belong to my family's history, as they belong to the history of one of its members. The inherent likeness that I am supposed to observe is simply not there. Dumped in a drawer of a wooden cabinet with hundreds of other photos, they fall outside of the family photo album as defined by James and Lobato. Not only by belonging to a physically bound collection but to a logical system determined by the quantitative and qualitative aspect of the one who is making the selection. To an extent, we could say that, even within the pile of unrelated photos, these constitute a logical whole and, therefore, stand out as a phenomenological album. However, that mental album is highly susceptible to my intervention as a viewer; I can influence the narrative, at least in making it closer to me. Thus, I add an epilogue to the logical whole. Simply by adding one more photo - the only one not made in Germany - I am significantly enlarging the emotional capacity of the whole narrative for me, personally. In this photo, we can see Živan, squatting alongside a fence, with three small children in front of him. The two children on his left and the one in the middle are Živan's nephew and niece. The scrawny looking, blonde, short-haired boy to his right is his youngest son, Borko, the one he had after returning from Germany - my grandfather. Though my existence necessitated a few more twists of fate, what we see in this photograph was one of the necessary preconditions. Highly symbolic, but that connection is unbreakable. Everything else remains under a big question mark.

25 James and Lobato, 20. John Berger cited from "Usos de la fotografia”, in Mirar, (Buenos Aires: Ediciones de la Flor, 1998), 69. 


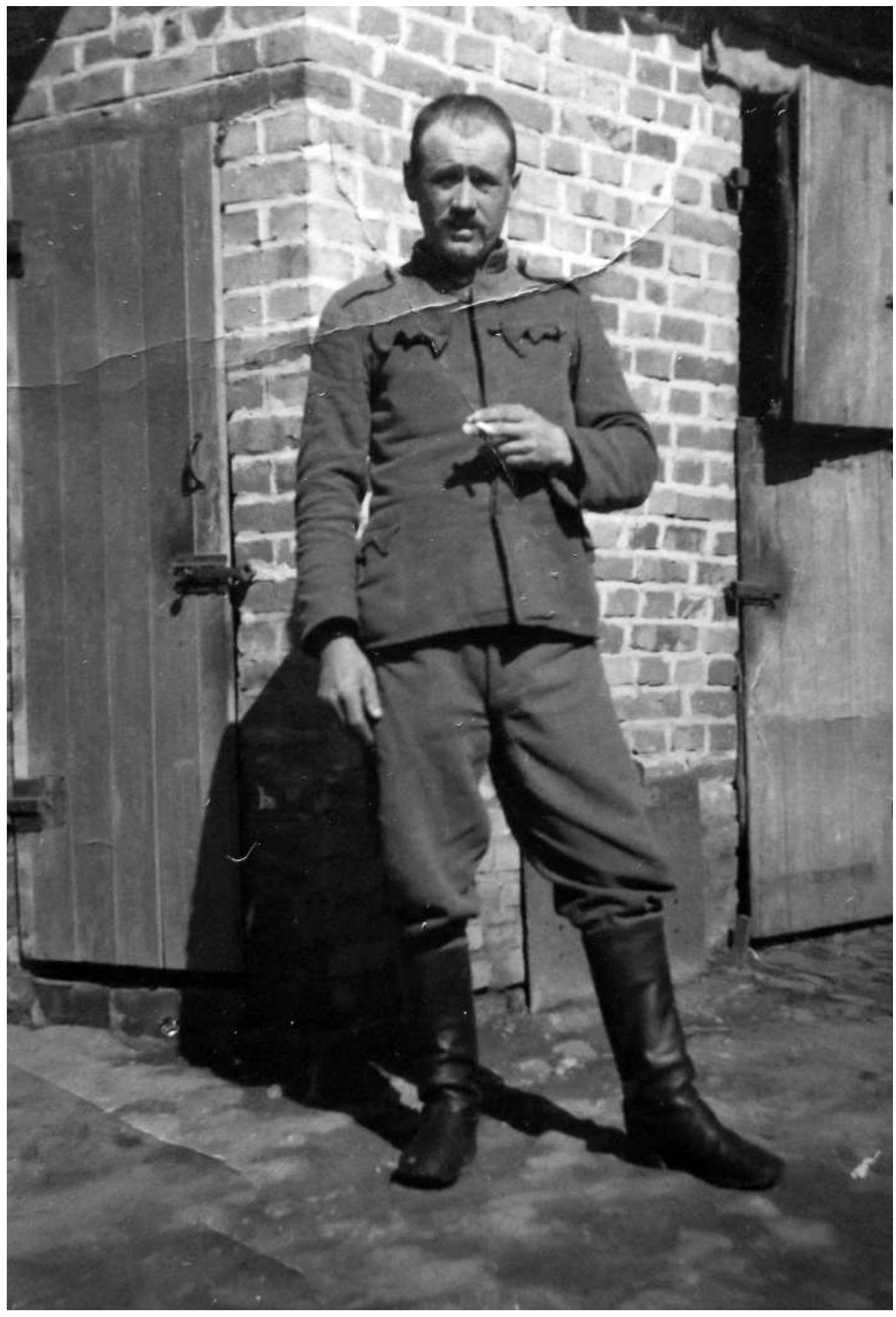

Figure 1. Živan Vuković in Stalag 6G, between April of 1941 and April of 1942. Unknown author. In the private collection of the author of the paper. 


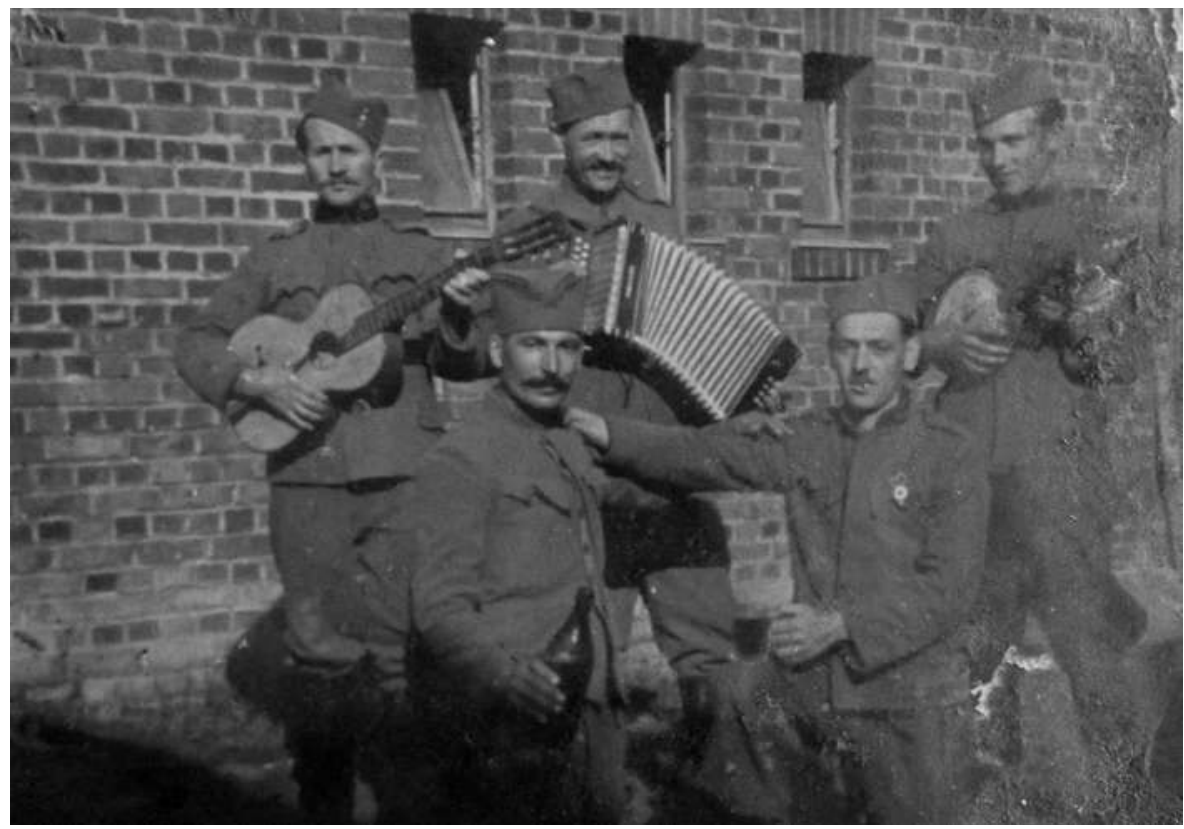

Figure 2. Živan Vuković (standing, with an accordion) in Stalag 6G, between April of 1941 and April of 1942. Unknown author. In the private collection of the author of the paper.

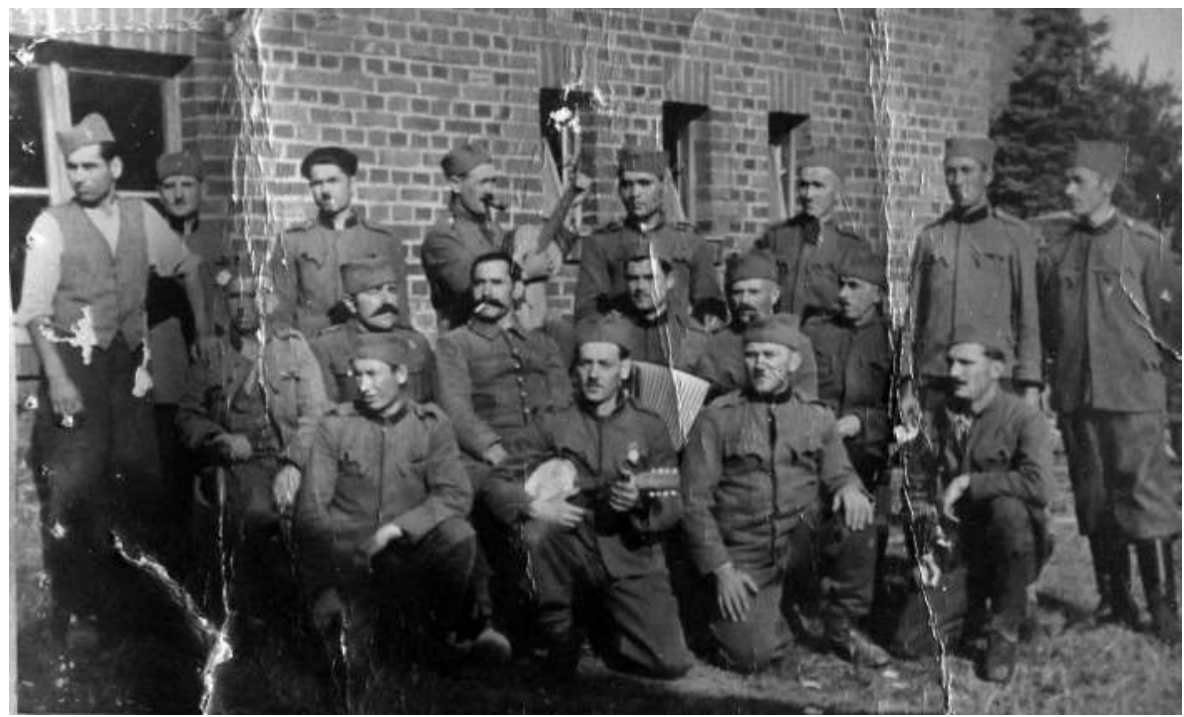

Figure 3. Živan Vuković (standing, with a guitar) in Stalag 6G, between April of 1941 and April of 1942. Unknown author. In the private collection of the author of the paper. 


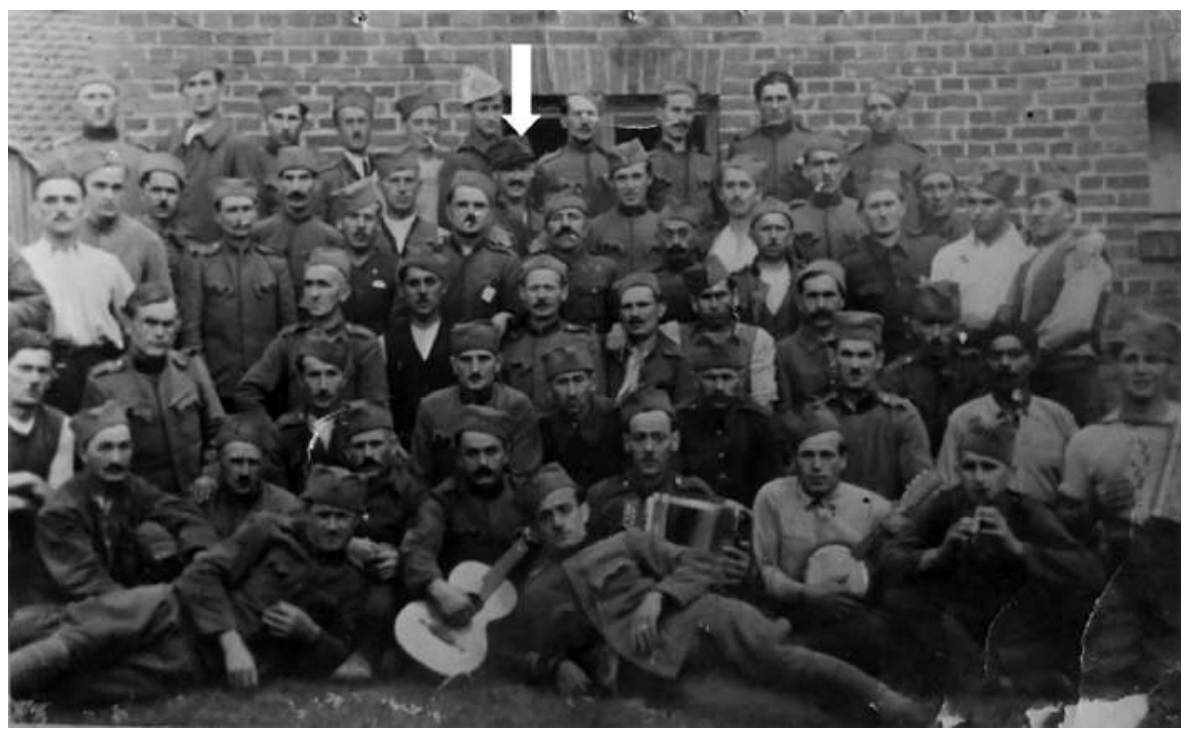

Figure 4. Živan Vuković (pointed at) in Stalag 6g, between April of 1941 and April of 1942. Unknown author. In the private collection of the author of the paper.

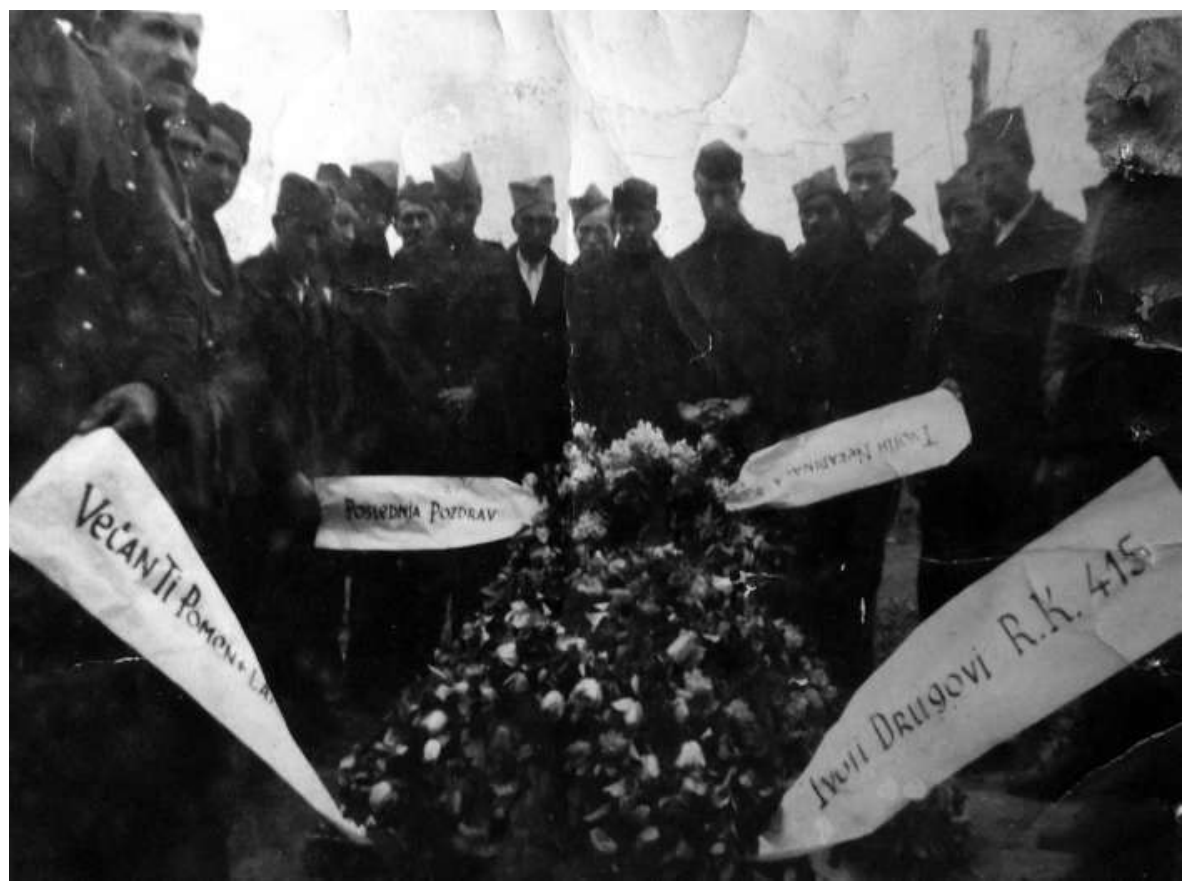

Figure 5. The funeral of an unknown soldier in Stalag 6G, between April of 1941 and April of 1942. Unknown author. In the private collection of the author. 


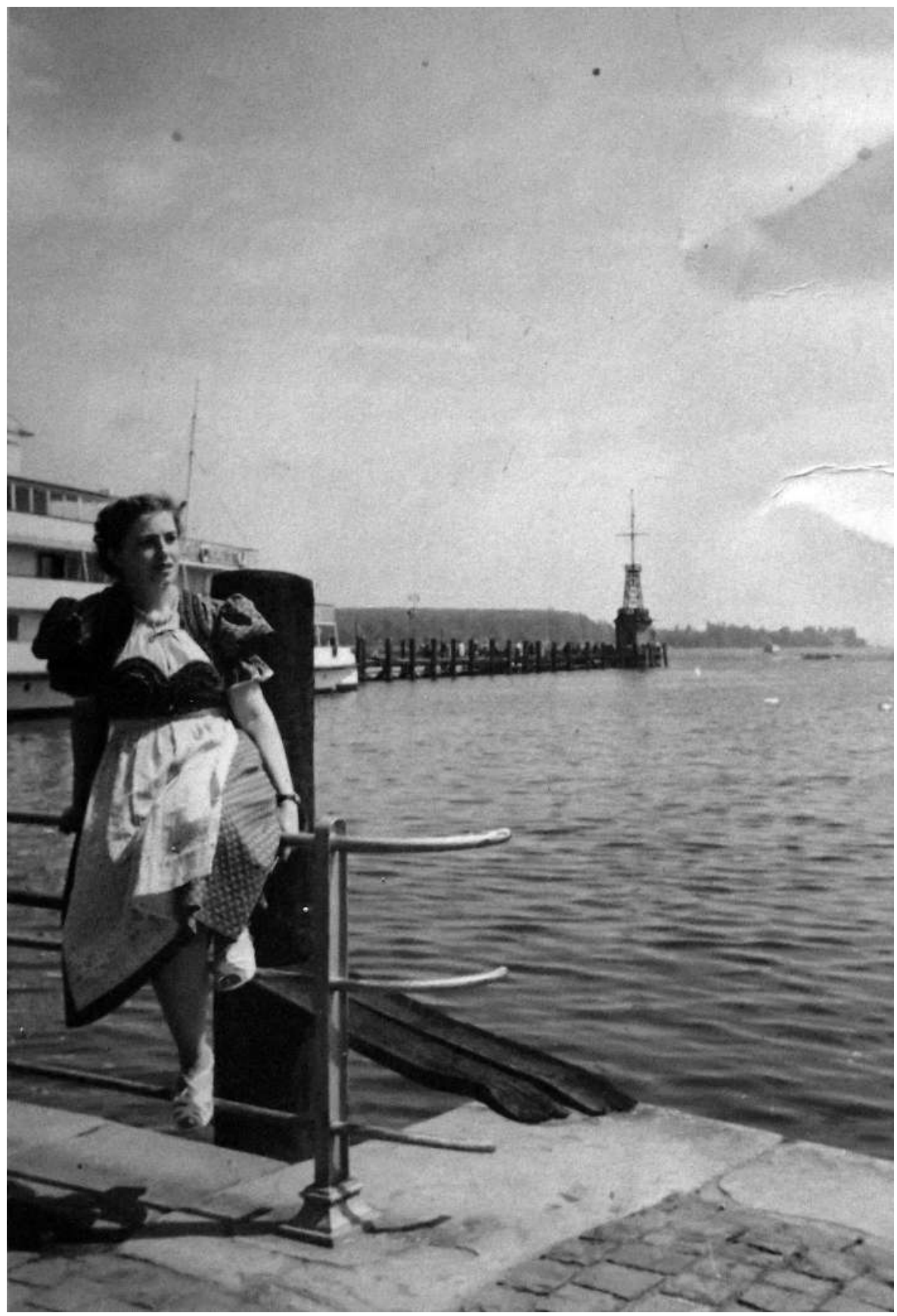

Figure 6. Lina? Made before December of 1953. Unknown author. In the private collection of the author of the paper. 


\section{Summary}

Used a lot more often as a primary source or, simply, as a tool of illustration, photography is rarely the subject of theoretical analysis. The theoretical assumptions used in this paper correlate photography with the accompanying text and question the limitations of contextuality, which photography assumes. The terms "recognition" and "excavation" set the border between the capacity of the observer to establish a personal connection to the subject and to come to terms with it as a part of his lived experience and analysis independent from that. Using the example of photographs of his great-grandfather, a prisoner of war during World War II, the author emphasizes the separation between himself - the observer and the subject (one which implies an emotional connection) that represents a distant object of historical analysis. Correlating the photograph and the accompanying text, the author questions the limits of the context of the visual representations and limits of the factual extraction. By posing new dilemmas and questions, photography has shown its limitations as a provider of definitive answers. A medium that has an undoubted potential to capture an instant, thus, providing a piece of information, is highly limited in its capacity to serve as a tool for narrative building. Eventually, photography is defined within the liminal space between knowledge and the lack thereof.

\section{Sources and Literature}

- Vuković family photo collection, in possession of the author.

- A letter by Živan Vuković, sent from a German POW camp on April 3, 1942, in possession of the author.

- A letter written by Lina to Živan Vuković, sent on December 15, 1953, in possession of the author.

- Oral testimonies by Borko Vuković, interview conducted in December of 2014. Notes in possession of the author.

- Video recording of oral testimonies by Clarence Earl Derrington Junior. Accessed on April 9, 2020. http://www.americanworldwartwo.amdigital. co.uk.proxyiub.uits.edu/Documents/Details/OH_3543_AM

- Barnes, Dustin. "Jackson man recalls POW time in WWII." The Clarion-Ledger, June 5, 2014. Accessed on April 9, 2020. https://www.clarionledger. com/story/news/2014/06/05/jackson-man-recalls-time-nazi-pow-campwwii/10048281/

- Azoulay, Ariella. The Civil Contract of Photography. New York: Zone Books, 2008. 
- $\quad$ Azoulay, Ariella. Civil Imagination: A Political Ontology of Photography. London - New York: Verso, 2011.

- Barthes, Roland. Camera Lucida. Reflections on Photography. New York: Hill and Wang, 2010.

- $\quad$ Benjamin, Walter. A Short History of Photography. Oxford: Oxford University Press, 2011.

- $\quad$ Berger, John, Jean Mohr. Another Way of Telling. New York: Pantheon, 1982.

- Coleman, Kevin. A Camera in the Garden of Eden: The Self-Foraging of a Banana Republic. Austin: University of Texas Press, 2016.

- Didi-Huberman, Georges. Images in Spite of All. Four Photographs from Auschwitz. Chicago: Chicago University Press, 2008.

- James, Daniel, Mirta Zaida Lobato. “Family Photos, Oral Narratives, and Identity Formation: The Ukrainians of Berisso". Hispanic American Historical Review 84/2004, 5-36. doi: 10.1215/00182168-84-1-5

- $\quad$ Langford, Martha. "Speaking the Album. An Application of the Oral-Photographic Framework". Locating Memory. Photographic Acts, eds Anette Kuhn, Kirsten Emiko McAllister. New York - Oxford: Berghahn, 2006.

- $\quad$ Lucaites, John Louis. "Visualizing 'The People': Individualism vs. Collectivism in Let Us Now Praise Famous Men". The Quarterly Journal of Speech 833/1997, 269-288. doi: 10.1080/00335639709384186

- Michaels, Walter Benn. The Beauty of a Social Problem: Photography, Autonomy, Economy. Chicago: University of Chicago Press, 2015.

- $\quad$ Scheck, Raffael. "Collaboration of the Heart: The Forbidden Love Affairs of French Prisoners of War and German Women in Nazi Germany". The Journal of Modern History 90/2018, 351-382. doi: 10.1086/697403

- The Familial Gaze, ed. Marianne Hirsch. Hanover-London: University Press of New England, 1999.

- $\quad$ Thomas, Julia Adeney. "The Evidence of Sight". History and Theory, Theme Issue 48/2009, 151-168.

- Wells, Liz. Photography: A Critical Introduction. London: Psychology Press, 2004. 


\title{
Резиме
}

Филип Митричевић

\section{Начини на које никада нисам размишљао о свом прадеди: есеј о потенцијалима фотографије као историјског документа}

\begin{abstract}
АпстрАКт: Овај рад је на трагу одговора на теоријско питање о потенцијалу фотографије као историјског извора. Он не претендује на класичну историјску реконструкцију, већ представља покушај да се на основу корелације узорка породичних фотографија, оралне историје и теоријских текстова покаже домет овог визуелног медија у историјском истраживању. Употребом веома израженог „личног гласа аутора“ рад претендује да одређена „посебна места“ доведе у везу са ширим контекстом и општом теоријом. У сврху показивања ограничености фотографије као историјског извора, аутор ће користити фотографије свог прадеде настале током заробљеништва у Другом светском рату.

КљУчНЕ РЕчИ: фотографија, Други светски рат, историографија, извори, Ролан Барт
\end{abstract}

Много чешће употребљавана као примарни историјски извор или просто у илустративне сврхе, фотографија се ретко узима као предмет теоријских разматрања. Теоријске представке у овом раду фотографију доводе у везу са пратећим текстом и преиспитују границе контекстуалности коју овај медиј поседује. Преко појмова „препознавања“ и „ископавања“ повлачи се линија између капацитета посматрача да успостави персоналну везу са приказаним субјектом и према њему се одреди као делу проживљеног искуства или као предмету потпуно независне анализе. Преко примера фотографија свог прадеде у заробљеничком логору током Другог светског рата аутор показује одвојеност између себе, посматрача, и субјекта који - иако подразумева одређену емотивну везу - представља удаљени објекат историјске анализе. Кроз однос фотографија и пратећег текста (писама послатих са фотографијама) испитани су лимити контекста визуелних представа и крајње границе фактуалне екскавације. Изазивајући увек нове дилеме и питања, фотографија се показала као врло ограничена у давању дефинитивних одговора. Медиј који 
има несумњив капацитет да овековечи тренутак и на тај начин пружи одређену информацију, лимитиран је у сврси изградње наратива. Фотографија се, на крају, дефинише у оквирима „граничног“ или „лиминалног“ простора између знања и његове недостижности. 